\title{
Involvement of Mothers in Educating Their Children on Family Life and Related Issues in Awka South LGA, Anambra State.
}

\author{
* Ilo Clementine Ifeyinwa, ${ }^{1}$ Agbapuonwu Noreen Ebelechukwu, ${ }^{2}$ Obasi Stella \\ Chinyelu, ${ }^{3}$ Makata Ngozi Eucharia \\ $R N, R M, B . S C, R P H N, M P H, M S C$ (FWACN), \\ $R N, R M, B . S C, R N T, M S C$ (FWACN), \\ B.SC, MSC, \\ $R N, R M, B . S C, R P H N, M P H,(F W A C N)$ \\ ${ }^{I}$ Department of Nursing Science. Nnamdi Azikiwe University Awka Anambra State \\ ${ }^{2}$ School of General Studies. Anambra State University Uli, Anambra State. \\ ${ }^{3}$ Enugu State Ministry of Health Enugu
}

\begin{abstract}
Five focus group discussions were held with 100 mothers of adolescent girls in Awka South LGA of Anambra State to assess their involvement in family life education for their children. The mothers perceived that girls should be told about menstruation only after attaining menarche and their fathers and brothers should not know about it. The girls were told at the time of marriage how they should behave with their parents-in-law, sister-in-law and husband. No information was given about what is intercourse, how conception occurred and on family planning measures. The mothers were uncomfortable about imparting family life education to their daughters. According to them, the girls can get information through their friends and elder sisters. Doctors, nurses, health personnel and teachers could impart family life education and this should be done to the girls only after attaining menarche.

Key words: Family life education, Behaviour change communication, Focus group discussions.
\end{abstract}

Background of the study

\section{Introduction}

Family life education is widely defined as the social construction of a biological drive and reflects issues of timing, frequency, duration, choice, and identity of sexual partners (Mishava, 2011). Education on reproduction according to Kodagoda (2009), describes the process of a human being coming into existence in stages including conception, development of the embryo and fetus, and the birth of the new baby. Kodagoda further stated that it includes such topics as sexually transmitted infections (STIs) and how to avoid them, as well as methods of contraception. Family life education programme include the standard anatomy, physiology and contraception content, wise decision-making about sex, how and when to choose abstinence, and ways to handle peer pressure (Furstenberg 2008)

According to Adeyemo (2006), mothers may choose to discuss issues on family life with their children or may decide to leave it to the school because they may feel uncomfortable in discussing sexuality. Nurses can assist mothers to work through their feeling of discomfort and provide them with appropriate resources and responses to their children's questions. Avert (2005) opined that in early adolescence, a child begins to develop the capacity for abstract and logical thinking. During this stage, adolescent's increasing interest in sexual anatomy and pubertal changes, mature emotionally and sexually. They may begin to engage in sexual behaviours such as masturbation among boys while petting sometimes progresses to oral sex, vaginal intercourse and anal sex by late adolescence. Adeyemo (2006) stated that it is extremely important for mothers to be aware of their right and duties to take up the initiative in the area of family life education. This is inevitable because the young people's formation in chastity and morality is so much dependent on the basic teaching of their mothers. As such, mothers should not shy away from this responsibility; rather they should teach their children before the roaring lion takes hold of their fates (Obi, 2007).

According to DiCenso (2008), mothers are duty bound to give more detailed explanation about sex and sexuality to their children because children naturally tend to confide in their mothers. It is this relationship of trust, friendship and confidence which have started in early first years of life that the mothers should capture the advantage of discussing sexuality with their children. Anguilar (2010) supported the opinion that mothers should help their children to understand the stages of physical and physiological developments of the genital organ; they should not allow them to get this information from friends or from people who are not well informed.

Researchers have found strong effects of parental supervision on the risk of premarital pregnancy and early sexual activity (Nzeagwu, 2007; Larimore, 2007; Obi, 2007 \& Powers, 2006). The trend and consequences of the adolescent premarital sex has raised crises among concerned youths (Obi, 2007). Efforts at curbing this social malady and at risk behaviour seem to be yielding little positive results. It therefore becomes necessary to 
assess the involvement of mothers in family life education of their children in Awka South LGA of Anambra State.

\section{Statement of Problem}

Adolescence is a crucial phase of life and a stressful period in which the adolescent tries to adjust to his/her varied physical, emotional and psychological changes (Sathe, 2008). According to Kirby (2009), the adolescent is curious to ask many questions but the problem is: whom to address these questions? Since talking about sex is a taboo in our society, the adolescents cannot freely approach his/her parents for guidance and those who courageously do are not well informed. This often makes a few of them who are curious to try to gather information through books, films, and internet or from friends who may not even have reliable information (Nzeagwu, 2007). There is a need to provide adolescents with reliable information so as to enable them to cope better with life changes. This need to educate the adolescents on family life education according to Ketting and Visser (2009) greatly lies on the mothers. Therefore this research was carried out to find out the involvement of mothers in family life education of their children.

\section{Purpose of the Study:}

1) To assess if mothers are involved in teaching of family life education to their children.

2) To find out the exact age mothers start imparting family life education to their children.

3) To find out what the contents of the family life education should be according to the mothers.

\section{Significance of the Study}

This study will help the mothers to know the importance of family life education to their children and to update their knowledge on sex and clear misconception and wrong information about sex. It will also help to provide practical guide for mothers, teachers and health care professionals to teaching behaviour change in family life education.

\section{Scope of the Study}

This study is limited to mothers who have adolescent children in Awka South Local Government Area of Anambra State.

\section{Research Questions}

1. To what extent are the mothers in Awka South LGA involved in teaching of family life education to their children?

2. At what age do mothers start imparting family life education to their children?

3. What are the contents of family life education that should be taught to the children according to the mothers in Awka South LGA?

\section{Method and Material}

The design adopted in this study was a descriptive survey research design which enabled a cross section of subjects of varying characteristics to be sampled and studied at the same time.

Data were collection through focus group discussion (FGD) of a group of twenty women who had adolescent daughters. Five such focus group discussions were conducted in the local government area with an average duration of 1 hour 30 minutes each and for a period of three days. Guidelines for Focus Group Discussion were prepared to assist in conducting the focus group discussion and contained questions pertaining to-

Their involvement in educating their children on family life issues.

At what age should it be imparted?

What should be the contents?

Who should impart the education on family life issues e.g. on marriage, boy - girl relationship, attitude towards an unmarried adolescent girl etc.

In order to make the mothers feel at ease, the discussion started with the introduction of each of the participants. Then the mothers were asked to discuss about themselves when they were adolescents and, later on, the questions were directed towards their adolescent daughters. The rules of the focus group discussion were explained to them- as far as possible, only one person should be allowed to talk at a time so that each participant could be heard clearly. The participants were informed that the discussion would be recorded in writing by the recorder so that this information could be used in developing the educational programme for the adolescent girls. 


\section{Results and Observations}

There were twenty participants in each group with ages ranging between 40 and 55 years. Some of the participants were literate while others were not literate. There were a total of 100 mothers who participated in

the study.

\section{Attitude of mothers towards education of girls}

All the participants felt that education was important.

"A minimum of Senior Secondary School Certificate is necessary for all and if they want to study further, they may continue."

Some mothers who had discontinued their daughters' education gave the following reasons for doing so:

"Because of financial constraint"

"Schools do not give them proper education."

The participants felt that girls should be financially independent to face any crisis in life.

"Girls need to be independent as one never knows what kind of husband she will get. If her husband leaves her, she should be able to earn money herself."

\section{Information imparted by mothers regarding menstruation}

The girls were not given any information about the physiology of menstruation and other physical changes occurring in the body.

"We will tell her it is a monthly occurrence, how she should maintain hygiene. She should not let her father and brothers come to know about it."

"One of the participants' daughter complained of pain in the chest during breast development for which the participant told her that it happens and she should not mention it to anybody."

"Girls should be told about menstruation only after attaining menarche."

"If the girl is told about menstruation before attaining menarche, then she will keep asking us constantly about when she will start her menses."

Knowledge about menstruation was poor among the participants.

"Even if our daughter asks us more questions, we are not able to clarify their doubts as we ourselves do not

know."

Attitude of mothers towards marriage of their daughters

Opinion was divided amongst the participants regarding marriage of their daughters. Some felt that it was essential to take into consideration the girl's opinion about marriage whereas some had still a very conservative attitude.

"Nowadays girls choose their own partners."

"If parents choose the husband for their daughters without taking their opinion, they blame the parents if any marital problems occur later."

"Sometimes girls threaten to commit suicide or may elope with the boy. It is better that we get the girl and the boy married rather than losing our daughter."

"If the girl chooses her own life partner, we will try to explain to her, but if she refuses to listen, we will resort to beating."

"The right age for marriage is between 18-25 years as the girl is matured enough and can think what is right and

what is wrong for herself."

Information imparted by mothers at the time of marriage

At the time of marriage, the girls were only told about maintaining good relations with members of the husband's family.

"We will talk to them about how they should behave with their husbands' families."

"We will tell them that they should listen to their husband and parents-in law."

"Nowadays girls already know a lot; there is no need for us to tell them. If they do not know, they will ask their friends."

"We cannot tell the daughter about the number of children she should have as it depends on her husband and in laws."

"If she has any health problem after marriage (pregnancy, abortion), then she will be given guidance."

Attitude of mothers towards boy - girl relationship

The girl is told not to talk to boys as she was now a grown-up. Talking to boys was considered wrong. 
"If I find my daughter talking to a boy, I will explain to her that it is wrong and that she should not talk to boys. If she does not listen to me, then I will beat her; her father will also beat her."

"Girls can only talk to boys in their neighbourhood who are their classmates."

\section{Attitude of mothers towards an unmarried girl} to be blamed.

Though the participants felt that both the girl and the boy were responsible, the girl was the one who is

"Both the girl and the boy are to be blamed."

"It is the girl's fault."

"It is the mother's responsibility to see that her daughter does not make any mistake."

"Society always blames the girls; so we have to see that our daughter does not commit any such mistake and

therefore we have to place restrictions on girls."

\section{Involvement of mothers towards imparting family life education}

The mothers were reluctant to talk about family life education and other related issues to their daughters as they found it embarrassing to discuss these issues.

"If girls are given sex education, the girls become smart and may experiment with sex."

"My daughter is innocent, how can I talk to her about sex. It will create a bad impression on her mind."

"I cannot tell my daughter about such things. It is embarrassing for us. Such information could be gotten from

friends, elder sister and sister-in-law."

\section{Who can impart family life education?}

There was a general consensus in all the groups that education on family life issues should be done by the doctors, nurses, teachers and health personnel. Information could also be gathered from friends and elder sisters. What should be the contents of family life education?

The mothers felt that information should be imparted on menstruation and conception. The girls should also be told about how to behave with their husband's family.

\section{Discussion of findings}

Family life education should be able to address all aspects of life especially the real life situations that adolescent find themselves while taking into consideration the age, level of exposure, socio-cultural and religious belief of the child. Although we see sexuality around us every day, family life education and services still remain a controversial issue in Nigeria. Surveys conducted nationally show that parents who ought to be the primary sexuality educators of their children and communicate to them specific values play the least role in this area. (AHI, 2005)

In a study conducted by Mishava (2010), it was observed that parents who ought to be the primary sexuality educator to their children have the following short comings.

a. They do not spend adequate time with their children and since children relate better with people they spend more time with (e.g. house helps), they learn values which may be against the family and the parent is not around to monitor, supervise and correct the risky values.

b. Some mothers even when they are around do not have the patient to thoroughly understand and relate well with their children to gain their confidence and approval.

Another major obstacle as identified in the study conducted by Irechukwu, (2008) was knowledge and confidence to teach psychosocial life skills to the children. Even when they were taught most mothers inform their children only about the health risks and potential negative consequences associated with sexual activity instead of a more balanced message. This results in calculated lies and many fearful stories about sex.

Our cultural heritage and religious believe do not allow issues relating to sexuality to be openly discussed to avoid breakdown of socio cultural and religious norms and values. They still believe that ignorance of sexuality issues will encourage chastity. The mothers educate and transmit the societal norms and culture to their children and also provide emotional, psychological and moral support. Mothers should make out time and form a real friendship with their children. They must share and communicate with confidence and spend pleasurable time with their children because they are the custodians of the next generation (AHI, 2005).

The present study shows that mothers have a favourable attitude towards sex education/ family life education. Incorporating topics, such as importance of the family, marriage and related values would enhance the favourable attitude of mothers towards such programmes. Poor knowledge about issues like changes which takes place during adolescence, conception, family planning and a feeling of embarrassment to discuss these issues 
hinder communication between the mother and the adolescent daughter. There is a need, therefore, to improve the knowledge and communication skills of mothers to enable them to be effective in imparting family life education.

The study also showed that mothers have more or less realized the importance of formal school education. If the education provided through regular schools is strengthened, more girls can easily pass their examinations. Schooling of girls can then easily continue beyond the SSCE level. If opportunities for vocational training for girls are strengthened at the community level, they would open a wide channel for adolescent health education programme, especially for girls. In such programmes, all the components of family life education i.e. reproductive and child health, family system and marriage in its right perspective, can be presented to adolescent girls. It would not only be acceptable to the parents but would also empower tomorrow's women and potential mothers. It will further make pregnancy special and safe.

\section{References}

[1]. Adeyemo M.O (2006). Dissemination of family life education to adolescents by their parents in suburban Ibadan, Nigeria. International Quarterly of Community Health Education; 15(3); 241-252.

[2]. AHI (2005) "Joy of sex education" edited by George Monbiot, The Guardian, 11 May 2005.

[3]. Anguilar, U. (2010) Sex Education in the U.S.: Policy and Politics". Issue Update. Kaiser Family Foundation. http://www.kff.org/youthhivstds/upload/Sex-Education-in-the-U-S-Policy-and-Politics.pdf. Retrieved 2010-05-23.

[4]. Avert, A. E. (2005) Adolescents In Changing Times: Issues And Perspectives For Adolescent Reproductive Health In The ESCAP Region United Nations Social and Economic Commission for Asia and the Pacific.

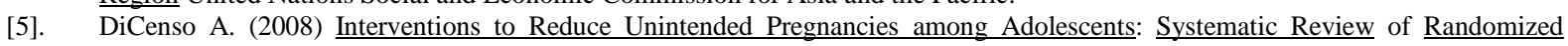
Controlled Trials. British Medical Journal 2002; 324:1426.

[6]. Furstenberg E. F (2008) Sexuality Education for Children and Adolescents - Committee on Psychosocial Aspects of Child and Family Health and Committee on Adolescence 108 (2): 498 - Pediatrics.

[7]. Irechukwu, C. (2008). Sex Education: Politicians, Parents, Teachers and Teens. The Guttmacher Report on Public Policy. Guttmacher Institute. http://www.guttmacher.org/pubs/tgr/04/1/gr040109.html. Retrieved 2010-05-23.

[8]. Ketting, E. and Visser, A. (2009). Contraception in the Netherlands: the low abortion rate explained. Patient Education and Counseling 23

[9]. Kirby, D. (2009). Emerging Answers: Research Findings on Programs to Reduce Teen Pregnancy. National Campaign to Prevent Teen Pregnancy. http://www.eric.ed.gov/ERICWebPortal/custom/portlets/recordDetails/detailmini.jsp?_nfpb=true\&_\&ERICExtSearch_SearchValue _0=ED456171\&ERICExtSearch_SearchType_0=no\&accno=ED456171.Homepage of the study.

[10]. Kodagoda N. (2009) Guidelines on Family Life Education from Sri Lanka .World Health Forum; 7; $281-285$.

[11]. Larimore, O. (2007). Reducing the risk of premarital adolescent sex: Focus on the family. Retrieved $28^{\text {th }}$ July 2010 from http://www.familyhealth.Org/teens/articles/aoooo253.html

[12]. Mishava, N. (2011) Changing Emphases in Sexuality Education in U.S. Public Secondary Schools, 2008-2009. Family Planning Perspectives32 (6). September/October 2011. http://www.guttmacher.org/tables/3220400t.html\#t3.

[13]. Nzeagwu, R. C. (2007). Comparative Analysis of Variables Influencing Premarital Sex Involvement among Secondary School Students in Imo State. Unpublished PhD Thesis, Nnamdi Azikiwe University Awka.

[14]. Obi, F (2007). Family Background and Premarital Sexuality among Secondary School Adolescents in Cross River State. Unpublished PhD thesis, University of Calabar.

[15]. Powers, D. A. (2006). Unobserved family effects on the risk of a first premarital birth.

[16]. Sathe A.G. (2008). Issues and problems in introducing family life education for boys and girls of secondary schools. Journal of Family Welfare; 38(1); 56-67. 